\title{
酸素化によるラット動脈管平滑筋細胞からのエラスチン分泌の減少
}

\author{
川上 翔士 ${ }^{1)}$, 南沢 享 ${ }^{1,2}$,
早稲田大学先進理工学部生命医科学科 ${ }^{1)}$,
東京慈恵会医科大学細胞生理学講座 ${ }^{2)}$
}

Key words :

ductus arteriosus, hypoxia, oxygen elastin, liquid chromatography tandem mass spectrometry

\section{Oxygenation Decreases Elastin Secretion from Smooth Muscle Cells of the Rat Ductus Arteriosus}

\author{
Shoji Kawakami ${ }^{1)}$, Susumu Minamisawa ${ }^{1,2)}$ \\ ${ }^{1)}$ Department of Life Science and Medical Bioscience, Waseda University, Tokyo, Japan \\ ${ }^{2)}$ Department of Cell Physiology, The Jikei University, Tokyo, Japan
}

Background: The ductus arteriosus (DA), a fetal arterial connection between the main pulmonary artery and the descending aorta, normally closes immediately after birth. The oxygen concentration in the blood rises after birth; in the DA, this increase causes functional closure, which is induced by smooth muscle contraction. Previous studies have demonstrated that hypoxia and/or oxygenation affect vascular remodeling. Therefore, we hypothesized that the rise in oxygen concentration would affect the vascular structure of the DA by producing proteins secreted from DA smooth muscle cells (SMCs).

Method and Results: We performed LC-MS/MS analyses to comprehensively investigate the secreted proteins in the supernatants of rat DA SMCs that were harvested under a hypoxic condition ( $1 \%$ oxygen) or under a normoxic condition $(21 \%$ oxygen). We found that the rise in oxygen concentration reduced the secretion of elastin from DA SMCs. Reverse transcriptionpolymerase chain reaction analyses also revealed that the expression levels of elastin mRNA were down-regulated in DA SMCs from a hypoxic to a normoxic condition.

Conclusion: Our in vitro study demonstrated that the rise in oxygen concentration reduced the secretion of elastin. Because elastin forms internal elastic lamina and elastic fibers in the vascular muscle layers, this study suggests that the rise in blood oxygen concentration after birth reduces the secretion of elastin, which may play a role in DA structural remodeling after birth.

要旨

背景：主肺動脈と下行大動脈を短絡する血管として知られる動脈管は，通常出生後直ちに閉鎖する。血中酸素濃度 は出生後に増加する. 動脈管ではこの酸素濃度上昇が動脈管平滑筋の収縮を引き起こし, 動脈管の機能的閉鎖を生 じる.一方, これまでの先行研究では低酸素や酸素投与が血管のリモデリングに影響することが報告されている。そ こでわれわれは酸素濃度の上昇が動脈管平滑筋から分泌されるタンパク質を介して血管構造に影響を及ぼしている と仮説を立てた.

方法と結果：われわれはLC-MS/MS 解析を行い, 低酸素下 (酸素 1\%) および正常酸素下(酸素 $21 \%$ )のそれぞれで培 養した, ラット動脈管平滑筋細胞の上清中の分泌タンパク質を網羅的に調べた. その結果, 酸素濃度の上昇により動 脈管平滑筋細胞から分泌されるエラスチンが減少することを見い出した. RT-PCR 解析においても低酸素下から通 常酸素下になることで動脈管平滑筋細胞においてエラスチン mRNAの発現が減少することを確認した.

結論：in vitro での本研究から酸素濃度の上昇によりエラスチンの分泌が減少することを見い出した。エラスチンは 内弾性板を形成し血管平滑筋層のエラスチン線維を形成することから, 今回の研究は出生後の血中酸素濃度の上昇 がエラスチンの分泌を減少させ, 出生後の動脈管構造のリモデリングにも影響している可能性を示唆するもので ある。

2012 年 12 月 12 日受付

2013 年 8 月 14 日受理
別冊請求先：干 105-8461 東京都港区西新橋 3-25-8 東京慈恵会医科大学細胞生理学講座 南沢 享 


\section{はじめに}

動脈管は肺動脈と下行大動脈をバイパスする胎生期 特有の血管であり，通常は出生後速やかに閉鎖する. 動脈管の閉鎖には機能的閉鎖と解剖学的閉鎖の二種類 の機序が働き, 恒久的な閉塞に至る。機能的閉鎖は出 生後のプロスタグランジン $\mathrm{E}_{2}$ の減少と自発呼吸によ る血中酸素濃度の上昇による血管収縮により引き起こ され, 特に酸素濃度の上昇はカリウムチャネルの働き を阻害し, 膜電位を上昇させる。これが電位依存性力 ルシウムチャネルの開口を促すことで, 細胞内カルシ ウム濃度が上昇し, 平滑筋の収縮に関与していること が報告されている1). 解剖学的閉鎖は動脈管平滑筋細胞 の血管内皮下への侵入や細胞外基質の蓄積などによる 血管内膜の肥厚が特徵的であり, その後アポトーシス の進行から血管の線維化を引き起こす2). この解剖学的 閉鎖には内腔が閉塞した後の低酸素状態が血管アポ トーシスの進行を促す因子であるという報告がある3). しかし胎生期の低酸素状態から, 出生後の呼吸開始に 伴って血中酸素濃度が上昇する過程で, 酸素濃度の変 化が動脈管リモデリングにいかに影響を与えている か, という研究はわれわれの知る限り報告されていな い.一方で, 血中酸素濃度に着目した遺伝子発現変化 に関する研究は行われており, ヒト肺動脈においては, 通常酸素濃度下と低酸素下に扔いて培養した平滑筋細 胞の遺伝子発現の違いについて DNA マイクロアレイ 法を用いて網羅的に調べたものなどがある4).

今回われわれは酸素濃度上昇によって動脈管から分 泌されるタンパク質が血管リモデリングに影響を及ぼ すという仮説のもと, 低酸素下で培養したラット動脈 管平滑筋細胞を通常酸素下に移し培養することで, 継 続して低酸素下で培養したものと比較し, その細胞か ら上清中に分泌されたタンパク質の変化を液体クロマ トグラフィー質量分析法 (Liquid Chromatography - tandem Mass Spectrometry, LC-MS/MS)というタンパク質を網 羅的に解析する装置で測定した.

\section{方 法}

\section{1. 動脈管平滑筋細胞の初代・継代培養}

胎生満期のウィスターラットを日本 SLC (静岡市)よ り購入し, 胎生 21 日の胎仔を帝王切開で取り出した後, その動脈管を摘出した. 摘出した動脈管を Collagenase/ dispase (Roche), Elastase Type II-A (SIGMA), Trypsin inhibitor type II-S (SIGMA), ウシ血清アルブミン(BSA) V (SIGMA)を混ぜた溶液中で $37^{\circ} \mathrm{C}, 15$ 分保温し, $1,000 \mathrm{rpm}$
で1 分遠心した後に上清を取り除いた。 そこへCollagenase II (Worthington biochem), Trypsin inhibitor type I-S (SIGMA), BSA V (SIGMA), HBSS (SIGMA)を混ぜた 溶液を加え, 再度 $37^{\circ} \mathrm{C} 12$ 分保温した後, $10 \% \mathrm{FBS}$ 入り DMEM を加え $1,000 \mathrm{rpm}$ で 3 分遠心, 上清を取り除き, 再度 $10 \% \mathrm{FBS}$ 入り DMEM を加え, よく擋拌して $3.5 \mathrm{~cm}$ 培養プレートに播種した。培養プレートは予め, PolyL-lysine Hydrobromide（Wako）でコーティングしたもの を使用した. その後, 動脈管平滑筋細胞を継代培養し, 4 継代目に扔いて一部のプレートにプロスタグランジ ン E2 受容体のひとつ, EP4 に対する刺激薬 (ONOAE1-329，10-6M) を投与し, 培養上清中のヒアルロン酸 濃度を測定した，われわれの先行研究では, 継代され た培養細胞が動脈管平滑筋細胞の性質を保有している 場合には, EP4 刺激薬によって, 上清中のヒアルロン酸 濃度が $50 \mathrm{ng} / \mathrm{mL}$ 以上の上昇がみられることが確認され ている. 本研究ではその条件に適した動脈管平滑筋細 胞のうち，6 継代目までの細胞を利用した。

\section{2. 低酸素刺激}

6 継代目までの動脈管細胞を 2 枚の培養プレートに播 種後, 細胞の定着を促すため 2 日間通常酸素下の細胞培 養器 $\left(\mathrm{O}_{2}: 21 \%, \mathrm{CO}_{2}: 5 \%, \mathrm{~N}_{2}: 74 \%, \mathrm{pO}_{2}: 163 \mathrm{mmhg}\right)$ で培 養し, その後 3 日間低酸素細胞培養器 $\left(\mathrm{O}_{2}: 1 \%, \mathrm{CO}_{2}\right.$ : $5 \%, \mathrm{~N}_{2}: 94 \%, \mathrm{pO}_{2}: 26.8 \mathrm{mmhg}$ )で培養した. その後, 本 研究では上清中に出てくる分泌タンパク質を測定する ために，低酸素下に抏いてあった血清を含まない DMEM で上清を替えた。一方を通常の $21 \% \mathrm{O}_{2}$ 下の細 胞培養器に戻し, もう一方は継続して低酸素細胞培養 器で培養を続けた。それぞれ細胞上清を 24 時間で回収 した，また，経時的な mRNA 発現量の変化を調べるた め, 前記とは別に, 同様の操作を行い, 通常酸素下の細 胞培養器に移した細胞について細胞懸濁液を 0 分, 1 時間, 24 時間で回収した(Fig. 1).

\section{計 測}

\section{1. 定量的リアルタイム PCR 解析}

TRIzol reagent (Invitrogen)を用いて total RNAを抽出 後, High Capacity cDNA Reverse Transcription Kit (ABI) を用いて cDNAを調製した. 調製したcDNAを Fast SYBR Green Master Mix (ABI)を用いて推奨されたプロトコル で qRT-PCR した. 内因性対照群にはミトコンドリア RNAの一つである $18 \mathrm{~S}$ を用いた. PCR プライマーは Table 1 にまとめたものを用いている. 


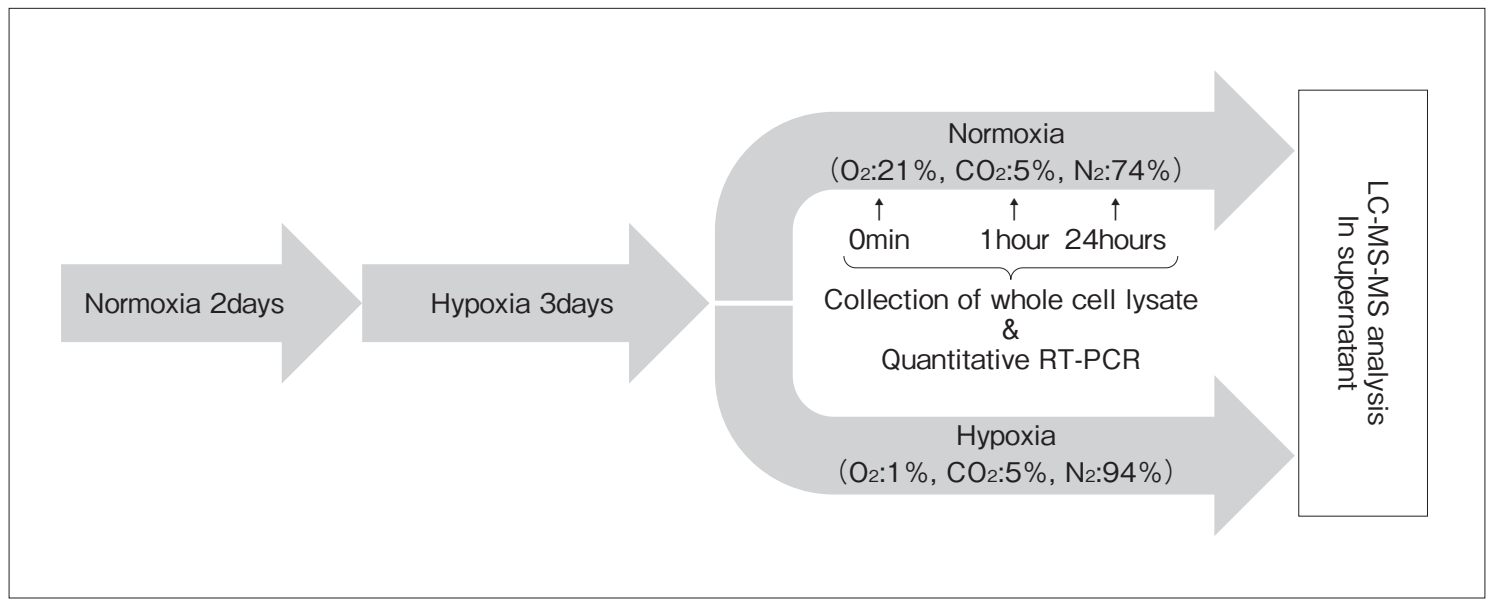

Fig. 1 Experimental design. We collected the culture media of DA smooth muscle cells under a normoxic or a hypoxic condition. For quantitative RT-PCR analyses, we also collected the whole cell lysates at 0 min, 1 hour, and 24hours after changing from a hypoxic to a normoxic condition.

Table 1 The primer sequences for quantitative RT-PCR analyses.

\begin{tabular}{clll}
\hline \multirow{2}{*}{ Gene } & NCBI ref_seq & \multicolumn{2}{c}{ Primer sequences } \\
\cline { 3 - 4 } & accession no. & \multicolumn{1}{c}{ Forward } & Reverse \\
\cline { 3 - 4 } VEGF & NM_001110333 & CCGGACGGGCCTCTGAAACC & GGTGCAGCCTGGGACCACTTG \\
Tropoerastin & NM_012722 & GCTATGGACTGCCCTATACCAA & CGCCTGTAATGCCTCCAA \\
Biglycan & NM_017087.1 & GGTTGGCCCTGACGGACAGAC & CGCATGGTCAATGTTCCTGGGGA \\
Fibronectin & NM_019143.2 & TGACCCCATCGACCAGTGCCA & CCCCAATGCCACGGCCGTAA \\
18S & NR_003286.2 & GTAACCCGTTGAACCCCATT & CCATCCAATCGGTAGTAGCG \\
\hline
\end{tabular}

\section{LC-MS/MS 解析}

通常酸素下と低酸素下での分泌タンパク質の比較を 行うため, 回収した細胞上清を Centrifugal Filter Units (MILLIPORE)を用いて平均 $0.03 \mu \mathrm{g} / \mu \mathrm{L}$ まで濃縮した. タンパク質濃度は標準用タンパク質として BSA を使 い, Quick Start Bradford プロテインアッセイキット （Bio-Rad）を用いて 595nm での吸光度を測定し計測し た. 濃縮細胞上清から標本あたりタンパク量 $0.2 \mu \mathrm{g}$ を使 い解析を進めた，それぞれの細胞上清を遮光したうえで, reduction buffer $[8 \mathrm{M}$, Urea; $500 \mathrm{mM}$, Tris- $\mathrm{HCl} ; 2.5 \mathrm{mM}$,

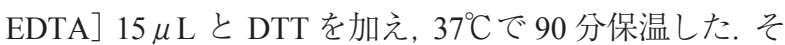
の後, $250 \mathrm{mM}$ iodoacetamide $5 \mu \mathrm{L}$ 加え, 再度 $37^{\circ} \mathrm{C}$ で 30 分保温 L, 50nM, Ammonium hydrogen carbonate を $180 \mu \mathrm{L}, \operatorname{trypsin}(200 \mathrm{ng} / \mu \mathrm{L})$ を $1 \mu \mathrm{L}, 100 \mathrm{mM}$ calcium chloride $0.08 \mu \mathrm{L}$ 加え, $37^{\circ} \mathrm{C} て ゙ 16$ 時間保温した. 最後 に3 回 ZIP-TIP 処理を行い精製し, LC-MS/MS (NanoFrontier eLD, HITACHI) 用いて質量分析を行っ た. Mascot Server (マトリックスサイエンス株式会社) の解析システムを用いて, 質量分析計から得られた質 量データに一致するアミノ酸配列をタンパク質やゲノ ムの配列データーベースから検索し，試料に含まれる
タンパク質を同定した，本実験の精度管理は，既報の ガイドラインに準拠して行った5).

\section{Western blot 解析}

回収した細胞上清を平均 $0.22 \mu \mathrm{g} / \mu \mathrm{L}$ まで濃縮後, 先 行研究 6) と同様の操作で Western blot解析を行った. 実 験では標本あたりタンパク質 $3.4 \mu \mathrm{g}$ 量を SDS-PAGE ゲルで泳動した. 1 次抗体は Anti-Elastin (Elastin Products Company, RA75)を使用し, 2 次抗体は AntiGoat HRP（SC-2020 J169）を使用した。目的タンパク質 の定量化は LAS-3000 imaging system (FUJIFILM, Tokyo, Japan）を使用して解析した。なお，今回の Western blotting では培養上清を用いたため, 比較対照 となる適当なタンパク質がないため, 本実験において はタンパク質量が一定であると仮定し, 対照で補正す ることなく，得られた值をそのままグラフ化した。

\section{結 果}

\section{1. 低酸素刺激の確認}

低酸素による刺激が細胞に影響を与えているのかを 


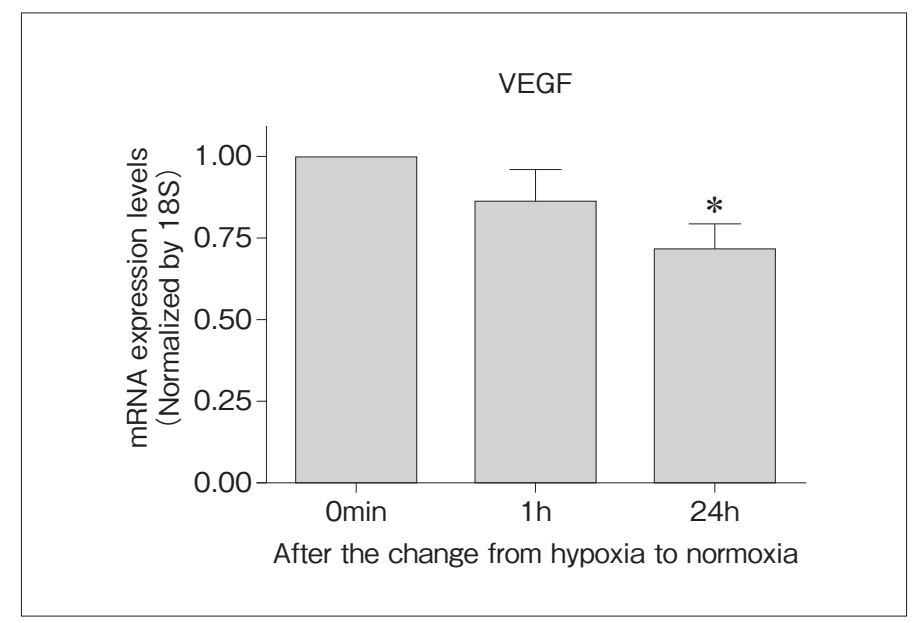

Fig. 2 The expression levels of VEGF mRNA in DA smooth muscle cells. The change from a hypoxic to a normoxic condition reduced its expression level.

$\mathrm{N}=6, *: \mathrm{p}<0.05$ (compared with 0min.)

Table 2 LC-MS/MS analysis on culture media of DA smooth muscle cells. The numbers indicate the ratio of secreted proteins in a normoxic to a hypoxic condition.

\begin{tabular}{lcccc}
\hline \multicolumn{1}{c}{ Protein name } & Sample1 & Sample2 & Sample3 & Average \\
\hline Elastin & $\mathbf{0 . 7}$ & $\mathbf{0 . 6 4}$ & $\mathbf{0 . 8 8}$ & $\mathbf{0 . 7 4}$ \\
Fibronectin & $\mathbf{0 . 9 5}$ & $\mathbf{0 . 7 4}$ & $\mathbf{0 . 9 4}$ & $\mathbf{0 . 8 8}$ \\
Biglycan & $\mathbf{0 . 9 7}$ & $\mathbf{0 . 6 4}$ & $\mathbf{1 . 0 6}$ & $\mathbf{0 . 8 9}$ \\
Extracellular superoxide dismutase & 0.91 & 0.85 & 1 & 0.92 \\
Protein NOV homolog & 1.05 & 0.62 & 1.1 & 0.92 \\
Collagen alpha-2 & 1.14 & 0.74 & 1.42 & 1.01 \\
Matrix Gla protein & 1.38 & 0.92 & 1.13 & 1.14 \\
\hline
\end{tabular}

確認するため, 低酸素から通常の細胞培養器に移した 平滑筋細胞サンプルについて 0 分, 1 時間, 24 時間で Vascular Endothelial Growth Factor(VEGF)の発現量を qRT-PCR を用いて測定した. 低酸素下で発現が増加す ることが知られているVEGFが通常酸素下に戻される ことで減少することが確認できた(Fig. 2).

\section{LC-MS-MS}

通常酸素下と低酸素下でそれぞれ 24 時間培養した 細胞上清について LC-MS/MS でその分泌タンパクを網 羅的に解析し，その結果を Normoxia/Hypoxia で示して ある(Table 2). Normoxia/Hypoxia の值が1より低いと, 通常酸素下でそのタンパク質の分泌が低酸素下で継続 して培養したものよりも低下したといえる.サンプル $1 \sim 3$ についてはそれぞれ別の親由来の胎仔動脈管を 採取し, 継代培養した動脈管平滑筋培養細胞を使って 実験している。この結果から, エラスチン, フィブロネ クチン, バイグリカンの分泌が通常酸素下の培養条件
で減少することがわかった。これらは細胞外マトリッ クスの主要構成因子であり, 中でもエラスチンは血管 において弾性線維を形成し，血管に弾力性を与える働 きをしていることが知られている.

\section{Western blot}

LC-MS/MS の結果を踏まえ, 細胞上清中に含まれる トロポエラスチンについて Western blot 法を用いてさ らに詳細に解析した(Fig. 3). トロポエラスチンはエラ スチンの前駆体である。この結果から, 通常酸素下に 置かれることで上清中に含まれるトロポエラスチンの 量が半分程度まで減少することがわかった。

\section{4. qRT-PCR}

低酸素から通常の細胞培養器に移した動脈管平滑筋 培養細胞について 0 分, 1 時間, 24 時間におけるトロ ポエラスチン, フィブロネクチン, バイグリカンの細 胞懸濁液中の mRNA 発現量を測定した(Fig. 4)。トロ 


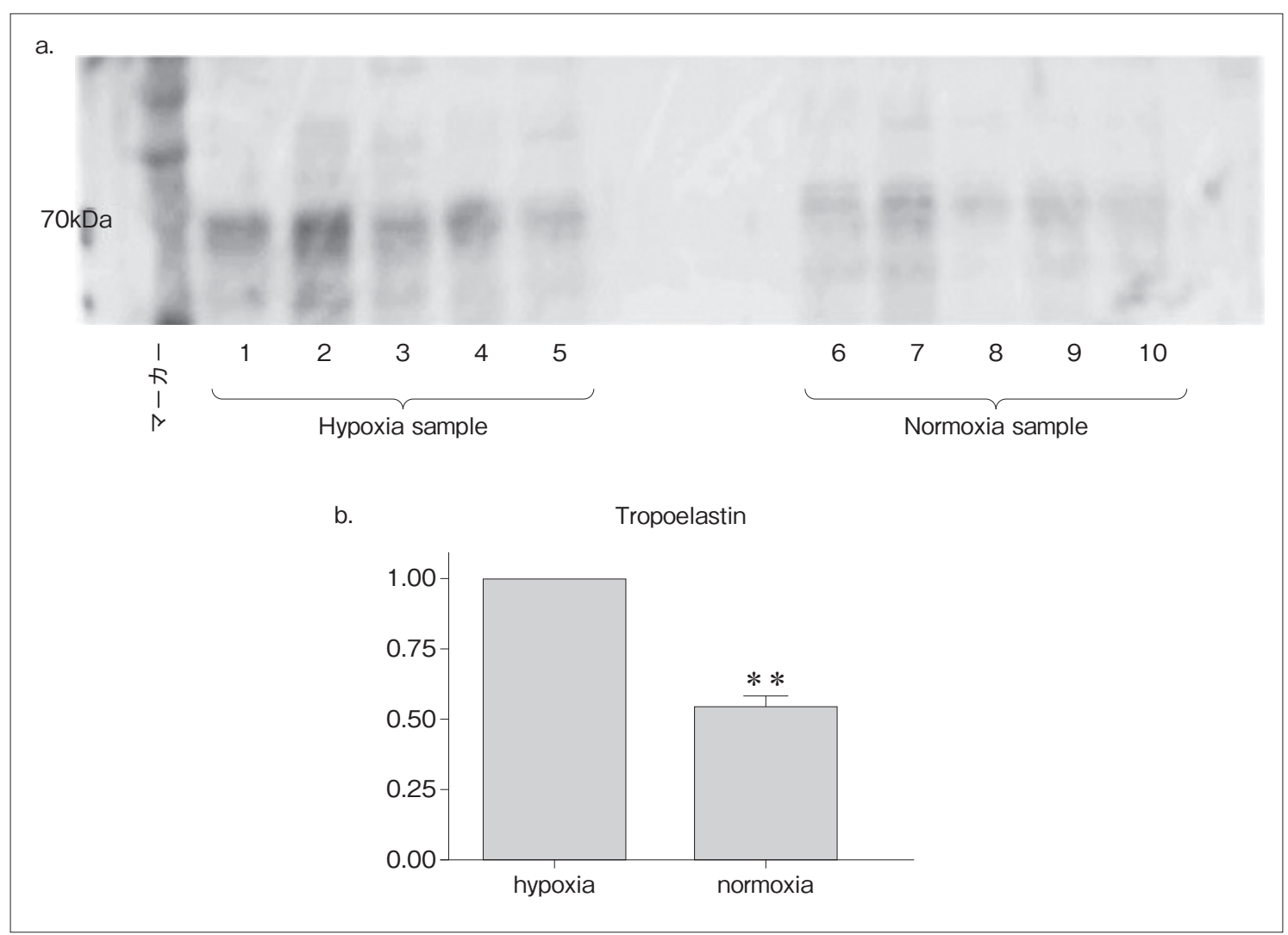

Fig. 3 The expression levels of elastin protein in culture media.

a : Sample numbers of 1 and 6, 2 and 7,3 and 8, 4 and 9, and 5 and 10 are the same origin of DA smooth muscle cells. $\mathrm{b}:$ The expression levels of elastin protein were decreased in a normoxic condition.

$\mathrm{N}=5, * *: \mathrm{p}<0.01$

ポエラスチンとバイグリカンの mRNA は 1 時間での減 少はみられたが, 24 時間後では変化がなかった。また フィブロネクチンについては 24 時間継続した減少が 確認できた。

\section{結 論}

低酸素刺激が適切に行われているかを確認する目的 で, 低酸素下から通常酸素下へ移した細胞懸濁液の VEGF mRNA を qRT-PCR で測定した実験では 24 時間 継続した mRNAの減少が確認できた。 なお，本研究に おいては, 低酸素状態のまま平滑筋細胞を培養し続け, 酸素化した細胞と同様の時間経過 (1 時間, 24 時間後) の状態での平滑筋細胞からは mRNA を回収していない ため, 厳密な意味では低酸素状態に比べて低下したと 断定できないかもしれない.しかしながら, 本研究で は細胞を播種してから 5 ～6 日目の $80 ９ 0 \%$ 融合状 態の細胞を使用しているため, VEGFをはじめとする 各遺伝子群の発現量は一定レベルに収束しており, 24
時間内では大きな変化がないことが推定される.VEGF は Hypoxia Inducible Factor(HIF)により活性化されるこ とが知られており, HIF は低酸素下では通常酸素下に 比ベそのタンパク質レベルでの発現が上昇する7,8)。し たがって，われわれはVEGF mRNAの低下を認めた結 果から低酸素刺激は適切に行われていると判断した。

次にLC-MS/MS の結果では, 通常酸素下でのエラス チン, フィブロネクチン, バイグリカンの減少が確認 できた，中でもエラスチンは血管の弾性に大きく影響 していることが知られている。また動脈管とエラスチ ンについて, 別のグループの先行研究では大動脈平滑 筋に比べ, 動脈管平滑筋ではエラスチンの減少により 細胞遊走がより促進される可能性も示唆されている99. エラスチンはトロポエラスチンや Fibrillin などの分子 間相互作用により形成されることが知られているが10), この中でトロポエラスチンについて Western blot を用 いて低酸素下と通常酸素下の細胞上清についてその含 有量を比較したところ, 通常酸素下に戻した細胞の上 清で細胞からのトロポエラスチンの分泌が半分程度ま 


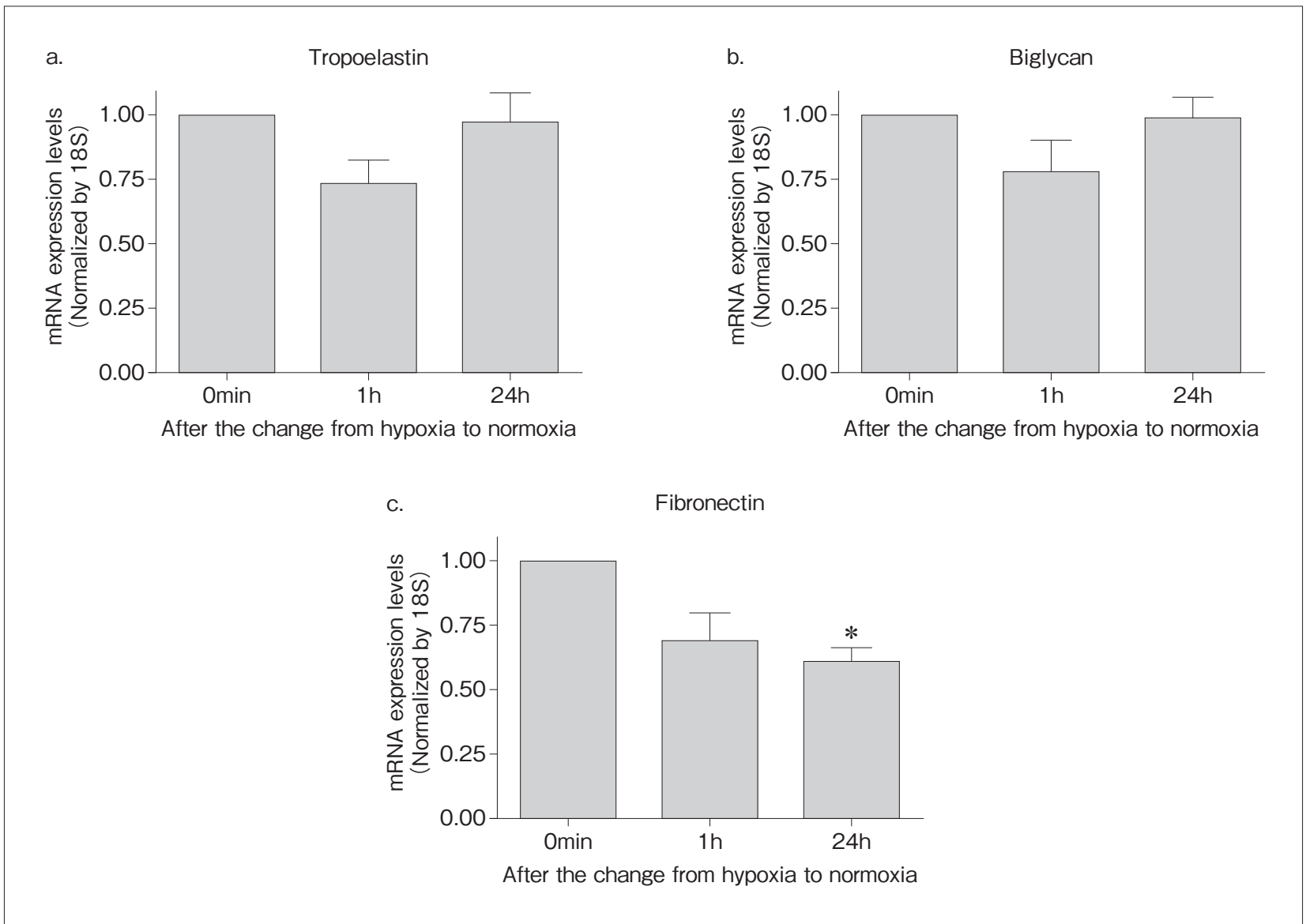

Fig. 4 The expression levels of tropoelastin, biglycan, and fiblonectin mRNAs. $\mathrm{N}=3, *: \mathrm{p}<0.05$ (compared with $0 \mathrm{~min}$ )

で減少していることがわかった(Fig. 3)。これらの結果 から, トロポエラスチンの上清中での減少が, エラスチ ンの減少の一因になっていると考えられる。 そこでわれ われは qRT-PCR を用いて, LC-MS/MS と Western blotで 減少が確認できたトロポエラスチン，フィブロネクチ ン, バイグリカンについてその細胞レベルでの mRNA 量の経時変化を検討した。 トロポエラスチンとバイグ リカンは 1 時間での減少がみられたが, 24 時間後では 低酸素下に置かれていた時 (Fig. 4 a, b 0min) と同様の発 現量であった(Fig. 4).この結果から, 細胞上清中のト ロポエラスチンの分泌減少に関連した mRNA レベルで の変化は確認できなかった。 今後はトロポエラスチン の分解促進の可能性も考えて実験を進めていきたい.

動脈管は出生後の血中酸素分圧変化にダイナミック に反応する血管であり, 血中酸素分圧による変化が, これまでに知られていたチャネル活性に関連した平滑 筋収縮による機能的閉鎖だけに留まらない可能性も考 えられる。われわれの知る限り, 酸素化が動脈管平滑 筋細胞でのエラスチン分泌を低下させる，という報告
は本研究が初めてである。他の細胞や組織を使った実 験において酸素化や低酸素によるエラスチン発現変化 をみた論文はあるが, 必ずしも一定の傾向がみられて はいない11 13). DNA マイクロアレイ解析を用いたわれ われの先行研究 ${ }^{14)}$ や Costa らの研究15) では, 出生前後 でエラスチン mRNA の変化は明らかではない.これら の実験では生体から摘出した組織そのものを使ってい るために, 単純に酸素化だけの影響をみているわけで はなく, 血行動態の変化など出生前後でのさまざまな 要因がエラスチン mRNA 発現に関与することを考慮し なくてはならない. 実際に, 動脈管の研究ではないが, エラスチン発現量は出生後に急激に増加することが知 られており，その大きな要因となるのが血圧などの機 械的ストレスの増加であると考えられている16).

一方, 機械的刺激がない状態での本研究結果は, 動 脈管の解剖学的閉鎖, という観点からみると臨床的に も興味深い. 動脈管はもともと大動脈などに比して弾 性線維の発達が不良であり, このことは出生後に容易 に閉塞しやすい点で合目的である2,17). 先に述べたよう 
に出生後の機械的刺激によって, 動脈管でもエラスチ ンは増加する可能性があるが, 酸素化によってそれが 相殺され, 全体として弾性線維の低形成を維持し, 閉 塞へと導きやすくしている可能性も示唆される。また, 新生児領域においては, 酸素化や低酸素状態での弾性 線維の形成変化は, 動脈管のみならず, 肺形成におい ても重要な課題であると考えられる.今回の培養細胞 での通常酸素下でのエラスチン減少の結果を踏まえ, 実際の生体内での影響についてさらなる研究が求めら れる。

\section{謝 辞}

当研究を行うにあたり実験指導およびデー夕解析に ご協力いただいた早稲田大学大学院先進理工学研究科 生命医科学専攻の岩井謙治先生ならびに, LC-MS/MS のデータ解析について貴重なアドバイスをいただいた 早稲田大学大学院先進理工学研究科生命理工学専攻の 加藤尚志教授に深謝致します.

\section{【参考文献】}

1) Waleh N, Reese J, Kajino H, et al: Oxygen-induced tension in the sheep ductus arteriosus: effects of gestation on potassium and calcium channel requlation. Pediatr Res 2009; 65: 285-290

2) Yokoyama U, Minamisawa S, Ishikawa $Y$ : Regulation of vascular tone and remodeling of the ductus arteriosus. J Smooth Muscle Res 2010; 46: 77-87

3) Clyman RI, Chan CY, Mauray F, et al: Permanent anatomic closure of the ductus arteriosus in newborn baboons: the roles of postnatal constriction, hypoxia, and gestation. Pediatr Res 1999; 45: 19-29

4) Manalo DJ, Rowan A, Lavoie T, et al: Transcriptional regulation of vascular endothelial cell responses to hypoxia by HIF-1. Blood 2005; 105: 659-669

5) Kocher T, Pichler P, Swart R, et al: Quality control in LC-
MS/MS. Proteomics 2011；11：1026-1030

6) Jiao Q, Bai Y, Akaike T, et al: Sarcalumenin is essential for maintaining cardiac function during endurance exercise training. Am J Physiol Heart Circ Physiol 2009; 297: H576-H582

7) Gao N, Ding M, Zheng JZ, et al: Vanadate-induced expression of hypoxia-inducible factor 1 alpha and vascular endothelial growth factor through phosphatidylinositol 3-kinase/Akt pathway and reactive oxygen species. J Biol Chem 2002; 277: 31963-31971

8) Ke Q, Costa M: Hypoxia-inducible factor-1 (HIF-1). Mol Pharmacol 2006; 70:1469-1480

9) Wachi H: Role of Elastic Fibers on Cardiovascular Disease. J Health Sci 2011； 57：449-457

10) Rabinovitch $M$ : Cell-extracellular matrix interactions in the ductus arteriosus and perinatal pulmonary circulation. Semin Perinatol 1996; 20: 531-541

11) Hilgendorff A, Parai K, Ertsey R, et al: Neonatal mice genetically modified to express the elastase inhibitor elafin are protected against the adverse effects of mechanical ventilation on lung growth. Am J Physiol Lung Cell Mol Physiol 2012; 303: L215-L227

12) Ambalavanan N, Nicola T, Li P, et al: Role of matrix metalloproteinase-2 in newborn mouse lungs under hypoxic conditions. Pediatr Res 2008; 63: 26-32

13) Berk JL, Hatch CA, Morris SM, et al: Hypoxia suppresses elastin repair by rat lung fibroblasts. Am J Physiol Lung Cell Mol Physiol 2005; 289: L931-L936

14) Jin MH, Yokoyama U, Sato Y, et al: DNA microarray profiling identified a new role of growth hormone in vascular remodeling of rat ductus arteriosus. J Physiol Sci 2011; 61: 167-179

15) Costa M, Barogi S, Socci ND, et al: Gene expression in ductus arteriosus and aorta: comparison of birth and oxygen effects. Physiol Genomics 2006; 25: 250-262

16) Wagenseil JE, Mecham RP: Elastin in large artery stiffness and hypertension. J Cardiovasc Transl Res 2012; 5: 264-273

17) Yokoyama U, Minamisawa S, Shioda A, et al: Prostaglandin $\mathrm{E}_{2}$ inhibits elastogenesis in the ductus arteriosus via EP4 signaling. Circulation 2013, [Epub aheod of print] 